\title{
Decomposition of tree litter: Interaction between inherent quality and environment
}

\author{
SYIFA RACHMAWATI ${ }^{1}$, TITUT YULISTYARINI ${ }^{2}$, KURNIATUN HAIRIAH ${ }^{1, \boldsymbol{v}}$ \\ ${ }^{1}$ Department of Soil Science, Faculty of Agriculture, Universitas Brawijaya. Jl. Veteran 1, Malang 65145, East Java, Indonesia. \\ Tel.: +62-341-551665, Fax.: +62-341-560011, ‘email: kurniatun_h@ub.ac.id \\ ${ }^{2}$ Purwodadi Botanical Gardens, Research Centre for Plant Conservation and Botanical Gardens, Indonesian Institute of Sciences. Jl. Raya Surabaya- \\ Malang Km.65, Purwodadi, Pasuruan 67163, East Java, Indonesia
}

Manuscript received: 24 April 2019. Revision accepted: 25 June 2019

\begin{abstract}
Rachmawati S, Yulistyarini T, Hairiah K. 2019. Decomposition of tree litter: Interaction between inherent quality and environment. Biodiversitas 20: 1946-1952. Litter layers protect forest soils, but may not be appreciated in recreation sites such as the Purwodadi Botanical Gardens (PBG), East Java, Indonesia. We quantified litter decomposition rates in mature stands of three tree species: mahogany (Swietenia macrophylla), angsana/narra (Pterocarpus indicus), and bungur/crape myrtle (Lagerstroemia thorelii). To separate inherent litter quality and stand-level environmental factors (such as microclimate, soil), decomposition rates were quantified for each species across all three stands. A possible interaction on decomposition rates is known as 'home-field advantage' (HFA). Litterweight loss from TSBF-standard litter bags was observed at $0,1,2,4,8$ and 12 weeks after litter bags were installed to estimate the halflife time $\left(\mathrm{t}_{50}\right)$. We also solicited visitor views on the presence of a thick litter layer on garden floor. Decomposition of angsana ( $\mathrm{t}_{50}=48$ weeks) was $15 \%$ faster at its 'own home' than in 'neighbors home'. No significant HFA effects were found in bungur/crape myrtle litter that decomposed slower in its home environment, while mahogany decomposition was independent of location. Generally, PBG visitors knew the benefits of litter and were not bothered by its presence; litter increased the attractiveness for visitors to enjoy their happy days under the shade of trees in a 'tropical autumn'.
\end{abstract}

Keywords: Crape myrtle, home-field advantage, litter decomposition, litter quality, mahogany, narra

\section{INTRODUCTION}

Litter layers on the ground reflect both the rate of litterfall and decomposition. The latter is understood as a product of nature (inherent characteristics of the plant species) and nurture (environment). Decomposition has mostly been studied from an ecological or agronomic perspective but has a specific context in tourist areas such as botanical gardens. Viewed from a tourist destination perspective, litter thickness is assumed to reduce the beauty of the environment and the comfort of visitors, hence the standard operational practices are to sweep it away and transfer it to compost heaps.

A botanical garden is a conservation area that has a documented collection of plants based on classifications of taxonomy, bioregion, theme, or a combination of these patterns for conservation, research, education, tourism, and environmental services (Presidential Decree No.93 2011) Purwodadi Botanical Gardens (PBG) in Pasuruan District, East Java, Indonesia is a place for conserving species of dry, low-elevation land areas, while attracting tourists to visit. It thus requires management that pays attention to aesthetics, cleanliness and environmental conservation. The gardens have three main types of trees planted in large areas, namely mahogany (Swietenia macrophylla), angsana/narra (Pterocarpus indicus), and bungur/crape myrtle (Lagerstroemia thorelii). The closed canopy of the mature stands is cooling the botanical gardens and influences microclimatic conditions (temperature and humidity of both air and soil) (Veen et al. 2015; Binkley and Adams 2019), Tree species differ in pattern, quantity and quality of litter-fall which affects soil microbial composition and $\mathrm{N}$ release from microbial activity (Midgley et al. 2015; Veen et al. 2015; Joly et al. 2017; Vivanco et al. 2018). and will have an impact on the acceleration of litter decomposition or home-field advantage (HFA). Interactions between generic effects of litter quality and aspects of the environment have been described (Ayres et al. 2009) as 'home-field advantage' (HFA) and may indicate that soil biota under specific vegetation has adapted to the chemical quality of the local litter. The HFA in decomposition rates can be evaluated by monitoring the rate of litter weight loss at the place of origin relative to its value in other places. Beyond the averaged 'main effect' of litter type and decomposition environment, interactions indicate positive of negative HFA phenomena. Internal quality factors ('nature') that influence the decomposition process of litter and $\mathrm{N}$ mineralization are the total $\mathrm{N}$, organic $\mathrm{C}$, lignin, and polyphenol concentrations (Mafongoya et al. 1998; Bradford et al. 2016), with various ratios and compound indices. Litter with high $\mathrm{N}$ levels but low levels of lignin and polyphenols will quickly decompose and make mineral $\mathrm{N}$ available to plants (Schuur et al. 2001; Sun et al. 2004), whereas organic matter with lignin levels > $15 \%$ and polyphenol concentration $>3 \%$ (Palm and Sanchez 1991) will stay longer on the soil surface, making them useful as mulch (Hairiah et al. 2000) 
The aims of this study were (i) to analyze rate of litter decomposition of mahogany (Swietenia macrophylla), angsana/narra (Pterocarpus indicus), and bungur/crape myrtle (Lagerstroemia thorelii) in various environmental conditions according to the "crossing method" or litter transfer, and (ii) to find out visitors' views on the presence of litter thickness in the botanical gardens.

\section{MATERIALS AND METHODS}

\section{Site description}

The study was conducted at Purwodadi Botanical Gardens (PBG) in Pasuruan District, East Java, at geolocation $7^{\circ} 47^{\prime} \mathrm{S}$ and $112^{\circ} 41^{\prime} \mathrm{E}$, from April-July 2018. Rainfall data from the four years of 2013-2017 (source: krpurwodadi.lipi.go.id) were classified into category B3 (Oldeman 1975) with 7 wet months (average per month > $200 \mathrm{~mm})$ and 5 dry months $(<100 \mathrm{~mm})$. Three types of land, each with main stands of mahogany (Swietenia macrophylla), angsana/narra (Pterocarpus indicus), and bungur/crape myrtle (Lagerstroemia thorelii) were selected for observation of tree density, basal area (BA), and dry weight of litter on soil surface.

\section{Physical-chemical characteristics of soil}

Soil samples were taken at 5 points with soil depth of 0 $10 \mathrm{~cm}$, mixed evenly, and air-dried for analysis of soil texture (pipette method), $\mathrm{pH}$, organic $\mathrm{C}$, and total $\mathrm{N}$. Measurement of soil bulk density (BD) was carried out by taking undisturbed soil samples from a depth of $0-10 \mathrm{~cm}$ and 10-20 cm using an iron box measuring $20 \mathrm{~cm} \times 20 \mathrm{~cm}$ $\mathrm{x} 10 \mathrm{~cm}$, then dried in an oven until the weight was constant. Observation of soil temperature was carried out every 3 days by inserting a thermometer slowly into the soil that has been punctured using a peg to a depth of 10 $\mathrm{cm}$, letting it stand for 10 minutes, and then recording the soil temperature.

\section{Litter decomposition rate}

Three litter types (mahogany, angsana/narra, and crape myrtle) were nested in the stands of these tree species. This allows comparison between decomposition rates at their 'own homes' (Mahogany in plot X, Angsana/narra in plot IX, and Crape myrtle in plot XI) with that at 'neighbours' homes' (Figure 1).

The tested litter was taken from the soil surface, air dried, and sub-samples were taken to be dried in an oven with a temperature of $80{ }^{\circ} \mathrm{C}$ for dry weight measurement. The litter quality was measured by determining levels of organic C (Walkley and Black wet extraction), total N (Kjehldal method), lignin (Goering and Van Soest 1970), and polyphenols (Anderson and Ingram 1993).

The amount of litter inserted into the litter bag $(0.5 \mathrm{~cm}$ mesh, sized of $25 \mathrm{~cm} \times 30 \mathrm{~cm} \times 3 \mathrm{~cm}$ ) is an average of $108.25 \mathrm{~g}$ (equivalent to the amount of standing litter presented in Table 2) and placed in each tested plot. Measurement of each treatment combination was repeated 5 times for a total of 45 bags taken per time of observation. Estimation of the rate of decomposition was based on the determination of the loss of litter in the field by taking out a litterbag sample per observation time (Anderson and Ingram 1993). The time of measurement was carried out at $1,2,4,8$ and 12 weeks after deploying litter bags on the soil surface.
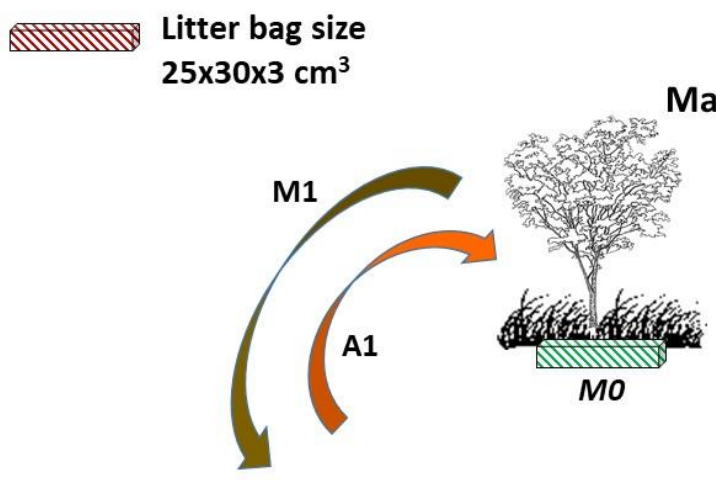

Mahogany (M)
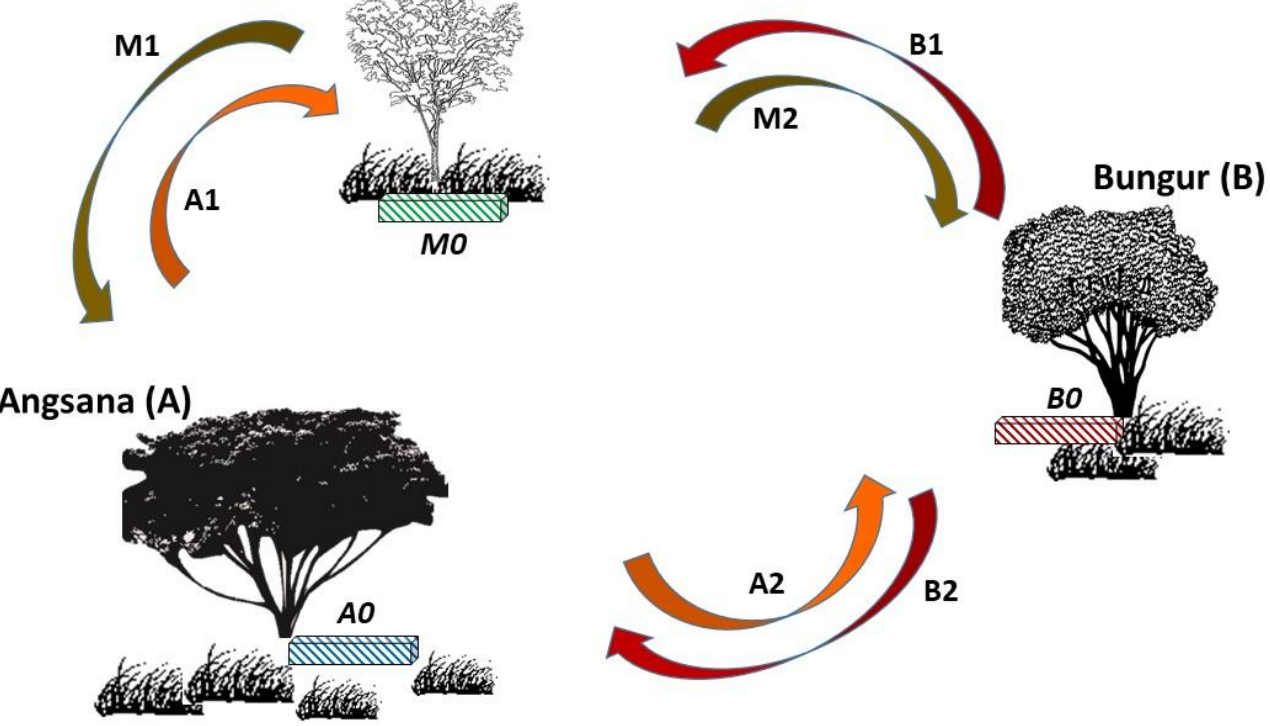

Figure 1. Schematic picture of litter transfer trial in three different conditions: in its 'own homes' compared to the 'neighbors' condition. Note: A: Angsana/narra, M: Mahogany, B: Bungur/crape myrtle; 0: 'own-home' environment, 1 and 2: neighbors-home environment 


\section{Measurement of litter mass loss and rate of decomposition}

Litter left in the litterbag was removed and put in a plastic bag to avoid loss of litter during transportation. The litter left in the litterbag was cleaned from the soil by letting it floating in a bucket of water. The floating litter was taken, drained in a filter, and air-dried. Then the litter was dried in an oven at $80^{\circ} \mathrm{C}$ for 48 hours before weighing the dry weight.

Rate of decomposition was determined by calculating the decomposition constant (k) using the equation developed by Olson (1963):

$$
\mathbf{X}_{\mathrm{t}}=\mathbf{X}_{\mathbf{0}} \mathrm{e}^{-\mathrm{kt}}
$$

Where,

$\mathrm{X}_{\mathrm{t}}$ : proportion of initial mass remaining at time $\mathrm{t}$ (grams)

$\mathrm{X}_{0}$ : proportion of initial mass (grams)

$\mathrm{t}:$ : time (weeks)

$k$ : decomposition rate $\left(k\right.$, week $\left.^{-1}\right)$

Based on the data from the calculation of the $\mathrm{k}$ value, the half-life $\left(t_{50}\right)$, which is the speed of litter loss by half of the initial weight that occurs in the first period of decomposition on the soil surface, can be calculated. According to Hairiah et al. (2006), the half-life can be calculated based on the following formula:

$$
\begin{aligned}
& \mathbf{t}_{\mathbf{5 0}}=\mathbf{- L n}(\mathbf{0 . 5}) / \boldsymbol{k} \\
& \mathrm{t}_{50}: \text { half-life litter (week) } \\
& \mathrm{k} \quad: \text { decomposition constant }
\end{aligned}
$$

\section{Calculation of home-field advantage}

Litter decomposition patterns often change when the litter is applied to other places with different environmental conditions. Decomposition patterns in its original place or in its 'own homes' are usually more profitable than in the new condition after transferring that is called 'neighbor's homes'; these conditions in sports competitions are usually referred to as 'home-field advantages' (Gholz et al. 2000; Ayres et al. 2009; Vivanco et al. 2018). Calculation of home-field advantage (HFA) decomposition was done by calculating the home-field advantage index (HFAI), using the equation developed by Ayres et al. (2009), which was done in three steps.

Step 1. Calculation of relative mass loss

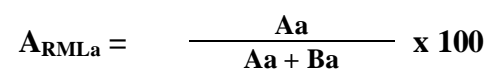

Where,

$\mathrm{A}_{\mathrm{RMLa}}$ : the relative mass loss of litter (or nutrient) from species $\boldsymbol{A}$ at site $\boldsymbol{a}$

$\mathrm{A}_{\mathrm{a}} \quad$ : the percent (of initial) litter mass (or nutrient) loss of plant species $\boldsymbol{A}$ respectively, decomposing at site $\boldsymbol{a}$

$\mathrm{B}_{\mathrm{a}} \quad$ : the percent (of initial) litter mass (or nutrient) loss of 'guest litter' species $\boldsymbol{B}$ respectively, decomposing at site $\boldsymbol{a}$
Step 2. Determining the overall HFA effects (where both litter species are considered)

$$
\text { HFAI }=\left[\frac{A_{\text {RMLa }}+B_{\text {RMLb }}}{2} / \frac{A_{\text {RMLb }}+\text { B }_{\text {RMLa }}}{2}\right] \times 100-100
$$

Where,

HFAI : home-field advantage index

$\mathrm{A}_{\mathrm{RMLa}}$ : the relative mass loss of litter (or nutrient) from species $\boldsymbol{A}$ at site $\boldsymbol{a}$

$\mathrm{A}_{\mathrm{RMLb}}:$ the relative mass loss of litter (or nutrient) from species $\boldsymbol{A}$ at site $\boldsymbol{b}$

$\mathrm{B}_{\mathrm{RMLa}}$ : the relative mass loss of litter (or nutrient) from species $\boldsymbol{B}$ at site $\boldsymbol{a}$

$\mathrm{B}_{\mathrm{RMLb}}$ : the relative mass loss of litter (or nutrient) from species $\boldsymbol{B}$ at site $\boldsymbol{b}$

HFAI represents the net value of increasing litter mass loss decomposed at the 'own home' compared to 'neighbors home' according to the litter-transfer method. HFAI calculations at each time of observation were carried out to see changes while the home-field advantage (HFA) occurs. An HFAI > 0 means that the litter decomposes faster at the 'own home', and there is HFA; HFAI $=0$ means that the rate of decomposition at the 'own home' is optimal, but a HFAI $<0$ means that there is no HFA (Clarke and Norman 1995; Ayres et al. 2009). (HFA)

Step 3. Calculation of mean home-field advantage

The average measurement of HFA was done to find out the percentage increase in the value of decomposition rates at the 'own home' compared to elsewhere in 'neighbor's home' using the equation developed by Austin et al. (2014):

Mean HFA $=\left(k_{\text {home }}-k_{\text {guest }}\right) / k_{\text {guest }} \times 100$

Where,

$k_{\text {home }}$ : decomposition constant $(k)$ at 'own home'

$k_{\text {guest }}$ : decomposition rate $(k)$ constant in 'neighbour's homes'

\section{Regression analysis}

Linear regression analysis was applied to test generic effects of temperature and litter quality indicators on the measured decomposition rates across litter types and environments.

\section{Botanical garden visitors' point of view on litter}

Visitors' views on the presence of litter on the soil surface will vary depending on the individual background. Determining the number of respondents depended on the number of visitors per period, calculated according to the formula by Slovin that could be accessed in http: //www.psai.ph/docs/publications/tps/tps_2012_61_1_9.pdf:

$$
\mathbf{n}=\frac{N}{1+N * e^{2}}
$$


Where,

$\mathrm{n}$ : Number of samples needed

$\mathrm{N}$ : Population size

e : Targeted confidence interval for proportions (0.1)

Based on the total number of visitors in 2017, which totaled 176,772 people, the suggested sample size was:

$$
\mathrm{n}=\frac{176,772}{1+176,772 *(0.1)^{2}}=99.94, \text { rounded to } 100
$$

Tejada and Punzalan (2012) summarized criticism on this method, but also indicated that more reliable calculation of a prior estimate of variability is needed, which was not available in our case.

\section{RESULTS AND DISCUSSION}

\section{Stand characteristics}

\section{Soil temperature}

The soil temperature of the three observation lands increased over time, from May to July 2018. Field measurements showed an average minimum temperature in the morning of $22{ }^{\circ} \mathrm{C}$ (Figure $2 \mathrm{~A}$ ) and a maximum daytime temperature of $24{ }^{\circ} \mathrm{C}$ (Figure 2B). The temperature of angsana/narra stand in both the morning and daytime was significantly $(\mathrm{p}<0.05)$ higher than the mahogany and bungur/crape myrtle stands with an average of $22.2^{\circ} \mathrm{C}$ and $24.3{ }^{\circ} \mathrm{C}$, respectively. There was no significant $(\mathrm{p}>0.05)$ difference of temperature in the mahogany and crape myrtle stands to average $21.7{ }^{\circ} \mathrm{C}$ and $23.9^{\circ} \mathrm{C}$ respectively in the morning and daytime.

\section{Physical-chemical characteristics of soil}

Soil in the experimental site had a moderate organic $\mathrm{C}$ total (average $>2 \%$ ), except for bungur/crape myrtle stands which on average only had $1.6 \% \mathrm{C}$ (Table 1). Total N levels were classified as moderate, ranging from $0.17 \%$ to $0.21 \%$. The $\mathrm{C} / \mathrm{N}$ ratio was classified as high in the angsana/narra stands (18\%), as medium in the mahogany stands $(11 \%)$, and $\mathrm{C} / \mathrm{N}$ in bungur/crape myrtle stands, with a low average of only $8 \%$. The soil reaction $(\mathrm{pH})$ at the experimental site was relatively acidic to neutral with a $\mathrm{pH}$ ranging from 5.7 to 6.4 .

The soil texture in the experimental site was silty clay, with an average content of $42 \%$ clay, $47 \%$ silt, and $11 \%$ sand (Table 1). The soil bulk density on angsana/narra stands showed an average of $1.0 \mathrm{~g} \mathrm{~m}^{-3}$, greater than that of mahogany and bungur/crape myrtle stands (average $0.8 \mathrm{~g}$ $\mathrm{m}^{-3}$ ). The mahogany and angsana/narra stands had a moderate organic $\mathrm{C}$ content, averaging $2.71 \%$, while the crape myrtle stand had a low organic C content of $1.6 \%$.

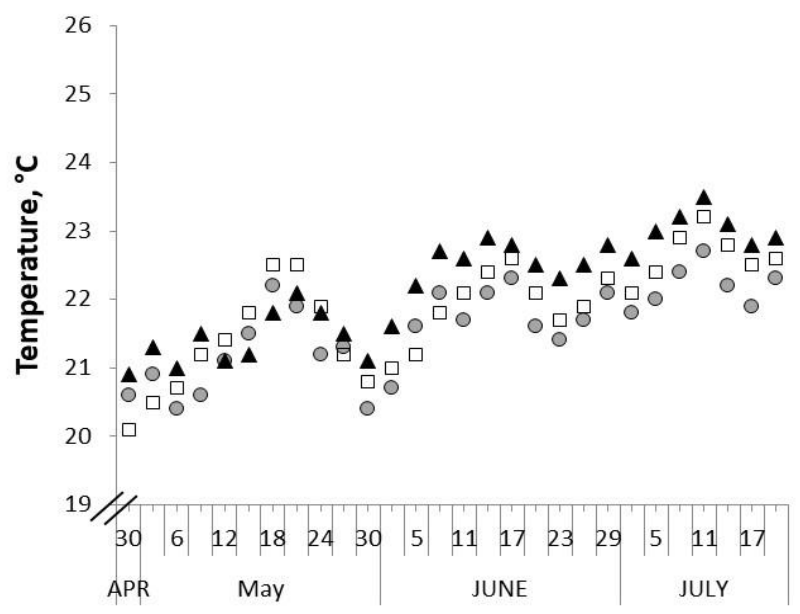

Time of measurement

A

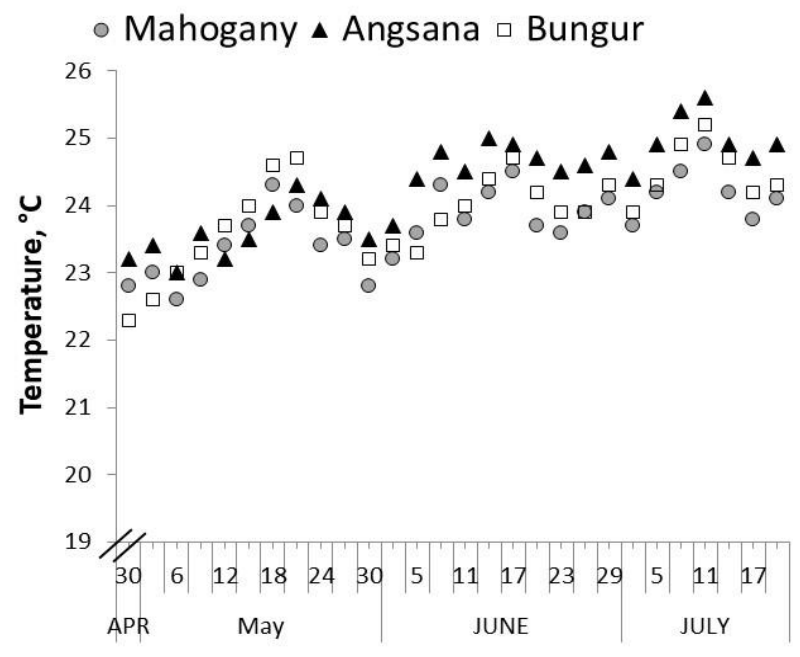

Time of measurement

B

Figure 2. Soil temperature was observed every 3 days (A) in the morning (between 7 AM and 8 AM) and (B) in daytime (between 1 PM and 2 PM) during the experiment (s.e.d. for morning and daytime temperature are 0.1973 and 0.1754 , respectively)

Table 1. Soil characteristics in each observation site at 0-10 cm depth, except for bulk density was in 0-10 $\mathrm{cm}$ and $10-20 \mathrm{~cm}$ depth

\begin{tabular}{|c|c|c|c|c|c|c|c|c|c|}
\hline \multirow{2}{*}{ Plot } & Total organic-C & Total N & \multirow{2}{*}{$\mathbf{C} / \mathbf{N}$} & \multirow{2}{*}{ pH } & \multicolumn{3}{|c|}{ Soil particle $(\%)$} & \multicolumn{2}{|c|}{ Bulk density $\left(\mathrm{g} \mathrm{cm}^{-3}\right)$} \\
\hline & $\%$ & & & & Sand & Silt & Clay & 0-10 & $10-20$ \\
\hline Mahogany & 2.43 & 0.22 & 11 & 6.6 & 5 & 42 & 53 & 0.83 & 0.82 \\
\hline Angsana/Narra & 2.99 & 0.17 & 18 & 5.7 & 7 & 49 & 44 & 1.02 & 0.99 \\
\hline Bungur/Crape myrtle & 1.61 & 0.21 & 8 & 6.4 & 16 & 44 & 40 & 0.76 & 0.81 \\
\hline
\end{tabular}


Tree population and Basal Area (BA)

The three tested sites showed different stand densities; angsana/narra had the lowest average with 135 trees $\mathrm{ha}^{-1}$, while the mahogany and bungur/crape myrtle stands had 600 and 500 trees $^{h^{-1}}$ (Table 2). As the differences between means between the stands far exceed two times the standard error of the mean, a null hypothesis of "no difference' can be readily rejected.

Although angsana/narra had the smallest number of trees per plot, its basal area (BA) $\left(\mathrm{m}^{2} \mathrm{ha}^{-1}\right)$ was the largest than two other stands, with an average of $22 \mathrm{~m}^{2} \mathrm{ha}^{-1}$, with $60 \%$ of the BA consisting of large trees $(\mathrm{DBH}>30 \mathrm{~cm})$; the average BA of mahogany and bungur/crape myrtle was 20 $\mathrm{m}^{2}$ ha $^{-1}$ (Table 2).

\section{Litter quality}

The amount of litter on the soil surface in the three observed stands was almost the same, $14-15 \mathrm{mg} \mathrm{ha}^{-1}$ (Table 2). Based on the chemical characteristics of the litter tested, all were classified as low quality, which was indicated by a lignin content of more than $15 \%$. Mahogany contains on average $37 \%$ lignin, with $21 \%$ lignin for angsana/narra and $30 \%$ for bungur/crape myrtle (Table 3), while the $\mathrm{C} / \mathrm{N}$ ratio ranged from 5-16 (Table 3). Palm and Sanchez (1991) stated that mineralization would occur rapidly if litter has a $\mathrm{C} / \mathrm{N}$ ratio $<25$, lignin of $<15 \%$, and polyphenol concentration of $<3 \%$.

Table 2. Stand density, diameter at breast height (DBH) and basal area (BA) in three observation stands

\begin{tabular}{|c|c|c|c|c|c|c|c|c|}
\hline Plot & $\begin{array}{c}\text { Standing } \\
\text { litter } \\
\left(\mathrm{mg} \mathrm{ha}^{-1}\right)\end{array}$ & $\begin{array}{c}\text { Stand } \\
\text { density } \\
\left(\text { trees ha }^{-1}\right) \\
\end{array}$ & $\begin{array}{l}\text { Mean } \\
\text { DBH } \\
(\mathrm{cm}) \\
\end{array}$ & $\begin{array}{l}\text { Total BA } \\
\left(\mathbf{m}^{2} \mathbf{h a}^{-1}\right)\end{array}$ & $\begin{array}{c}\text { BA-Large } \\
\left(\mathbf{m}^{\mathbf{2}} \mathbf{h a}^{-1}\right)\end{array}$ & $\begin{array}{c}\text { BA-Med }^{\mathbf{b}} \\
\left(\mathbf{m}^{2} \mathbf{h a}^{-1}\right)\end{array}$ & $\mathbf{n}$ & s.e.m \\
\hline Mahogany & 14.4 & 600 & 19.8 & 21.0 & 0 & 21.0 & 24 & 0.11 \\
\hline Angsana/narra & 14.2 & 135 & 46.7 & 22.0 & 12.9 & 9.01 & $\begin{array}{c}8^{\mathrm{a}} \\
19^{\mathrm{b}}\end{array}$ & $\begin{array}{l}0.34^{\mathrm{a}} \\
0.12^{\mathrm{b}}\end{array}$ \\
\hline Crape myrtle & 14.7 & 500 & 20.5 & 19.1 & 0 & 19.1 & 20 & 0.15 \\
\hline
\end{tabular}

Note: ${ }^{\text {a }}$ Large $=$ large tree $(\mathrm{DBH}>30 \mathrm{~cm}) ;{ }^{\mathrm{b}} \mathrm{Med}=$ medium tree $(\mathrm{DBH}=15-30 \mathrm{~cm}) ; \mathrm{n}=$ number of samples, s.e.m=standard error of means

Table 3. Initial chemical litter composition of mahogany, angsana/narra, crape myrtle and litter quality category according to Palm and Sanchez (1991)

\begin{tabular}{|c|c|c|c|c|c|c|c|c|}
\hline \multirow{2}{*}{ Species } & Total C & Total N & Lignin & Polyphenol & \multirow{2}{*}{$\mathrm{C} / \mathrm{N}$} & \multirow{2}{*}{$\mathbf{L} / \mathbf{N}$} & \multirow{2}{*}{$(\mathbf{L}+\mathbf{P}) / \mathbf{N}$} & \multirow{2}{*}{$\begin{array}{l}\text { Category of } \\
\text { litter quality }\end{array}$} \\
\hline & \multicolumn{4}{|c|}{$\%$} & & & & \\
\hline Mahogany & 22.1 & 1.4 & 37.3 & 5.3 & 15.8 & 26.7 & 30.5 & Low \\
\hline Angsana/Narra & 15.3 & 2.1 & 21.2 & 4.1 & 7.93 & 10.3 & 12.3 & Low \\
\hline Bungur/Crape myrtle & 16.3 & 1.2 & 30.0 & 10.2 & 13.5 & 24.8 & 33.2 & Low \\
\hline
\end{tabular}

Table 4. Litter decomposition rate ( $k$ value) and half-life time ( $\left.\mathrm{t}_{50}\right)$

\begin{tabular}{|c|c|c|c|c|c|c|}
\hline Litter species & Plot $^{a}$ & Equation & $\mathbf{R}^{2}$ & $k$, week $^{-1}$ & $1 / k$, week & Half-life $\left(t_{50}\right)$, week \\
\hline \multirow{3}{*}{ Mahogany } & DM & $y(M)=1.039 x^{-0.12}$ & $\mathrm{R}^{2}=0.7910$ & 1.039 & 90 & 62 \\
\hline & DA & $\mathrm{y}(\mathrm{M})=1.0446 \mathrm{x}^{-0.135}$ & $\mathrm{R}^{2}=0.8026$ & 1.0446 & 86 & 60 \\
\hline & DB & $\mathrm{y}(\mathrm{M})=1.0337 \mathrm{x}^{-0.108}$ & $\mathrm{R}^{2}=0.8003$ & 1.0337 & 94 & 65 \\
\hline \multirow[t]{3}{*}{ Angsana/Narra } & $\mathrm{DM}$ & $y(A)=1.0723 x^{-0.186}$ & $\mathrm{R}^{2}=0.7441$ & 1.0723 & 80 & 55 \\
\hline & DA & $\mathrm{y}(\mathrm{A})=1.0935 \mathrm{x}^{-0.236}$ & $\mathrm{R}^{2}=0.7762$ & 1.0935 & 70 & 48 \\
\hline & DB & $\mathrm{y}(\mathrm{A})=1.055 \mathrm{x}^{-0.156}$ & $\mathrm{R}^{2}=0.7782$ & 1.055 & 82 & 57 \\
\hline \multirow[t]{7}{*}{ Bungur/Crape myrtle } & $\mathrm{DM}$ & $\mathrm{y}(\mathrm{B})=1.0517 \mathrm{x}^{-0.149}$ & $\mathrm{R}^{2}=0.7876$ & 1.0517 & 85 & 59 \\
\hline & DA & $\mathrm{y}(\mathrm{B})=1.049 \mathrm{x}^{-0.151}$ & $\mathrm{R}^{2}=0.8286$ & 1.0490 & 80 & 55 \\
\hline & $\mathrm{DB}$ & $\mathrm{y}(\mathrm{B})=1.0398 \mathrm{x}^{-0.123}$ & $\mathrm{R}^{2}=0.8149$ & 1.0398 & 93 & 65 \\
\hline & & & & & Mean & 41 \\
\hline & & & & & STD & 3.95 \\
\hline & & & & & $\mathrm{n}$ & 12 \\
\hline & & & & & s.e.m. & 1.19 \\
\hline
\end{tabular}

Note: ${ }^{a}$ DM: mahogany, stand; DA: angsana/narra stand; DB: bungur/crape myrtle stand; STD: Standard Deviation, n: number of samples, s.e.m: standard error of means 


\section{Litter decomposition rate}

Based on the measurement results of litter mass loss per observation shown in Table 4, the litter decomposition rate varied from sites to sites. In the case of angsana/narra, the fastest decomposition $\left(k=1.0935\right.$ and half-life $\mathrm{t}_{50}=48$ weeks) occurred at the 'own home' environment ('homefield advantage') while in 'neighbours home' have averaged $\mathrm{t}_{50}>55$ weeks, whereas bungur/crape myrtle $(k=$ $1.0398 ; \mathrm{t}_{50}=65$ weeks) was the opposite. Mahogany was a slow decay type of litter in various environmental conditions, with $k$ values ranging from 1.0337-1.0446; $\mathrm{t}_{50}$ ranging from 60-65 weeks. The angsana/narra case relates to the statement of Gholz et al. (2000) and Ayres et al. (2009) that litter can decompose more quickly in its 'own home' than elsewhere in 'neighbors home', with different environmental conditions. It is suspected that the presence of 'guest' litter from other environments allows competition between soil biota in decomposing litter that has not been previously known, causing soil organisms to work selectively (Ayres et al. 2009).

The data of litter decomposition rates in PBG can be grouped in three categories: quick decomposition with a $t_{50}$ $\leq 55$ weeks, slow decomposition with $t_{50} \geq 65$ weeks, and moderate decomposition with $\mathrm{t}_{50}=55-65$ weeks .

\section{Home-field Advantage (HFA)}

According to Aerts et al. (1997), Wang et al. (2014), and Veen et al. (2015), HFA can be caused by decomposer activity from either inside or outside the original environment. Based on calculated home-field advantage index (HFAI), it was found that positive HFA occurred at the beginning of the week and the final week of observation, while at the $2^{\text {nd }}$ week $($ HFAI $=0.1)$ and $4^{\text {th }}$ week (HFAI = -1), HFA did not occur (Figure 3).

Mean HFA of angsana/narra (18.7) was positive, meaning that the rate of decomposition was faster in its 'own home' than elsewhere in the 'neighbor's home', while that of mahogany and bungur/crape myrtle litter was negative (-8.26 and-6.14, respectively (Figure 4), implying that the decomposition rate occurred faster in the neighboring home environments.

Regression of ion of decomposition rate on temperature and litter quality indicators

The decomposition rate ( $\mathbf{k}$ value) was closely related to the soil temperature (Figure 5). Higher temperatures in more open tree canopies speed up decomposition, leading to a reduction of the protective function of undecomposed litter in reducing drought risks (Zimmerman et al. 2015).

Regression of decomposition rate ( $k$ value) on litter quality indicators (Table 5) showed a strongest $\left(R^{2}=0.66\right)$ relation with $\mathrm{C} / \mathrm{N}$ ratio of the litter and weak effects of lignin and polyphenol levels.

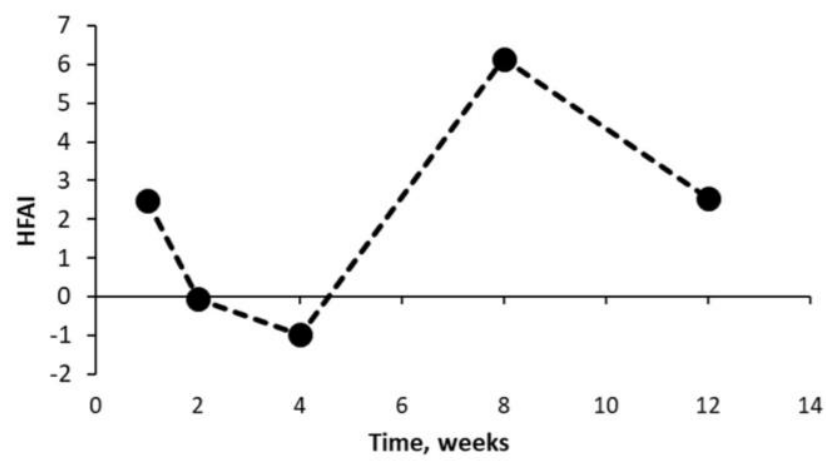

Figure 3 Home-field advantage (HFA) index all type of litter at various time of observations

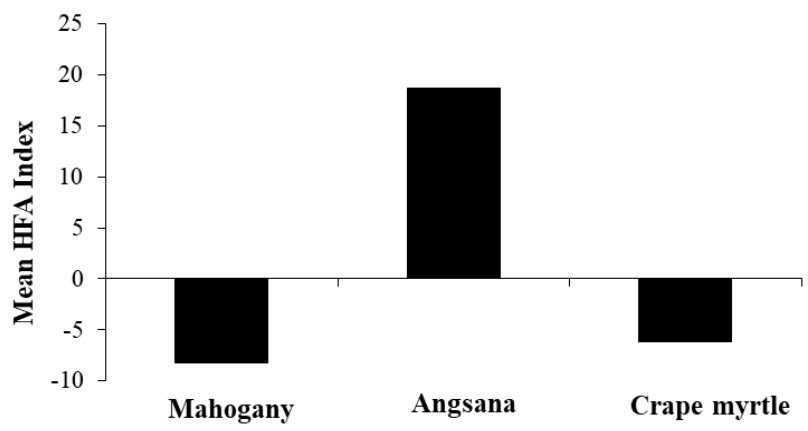

Figure 4. Mean HFA of mahogany, angsana/narra, and bungur/crape myrtle

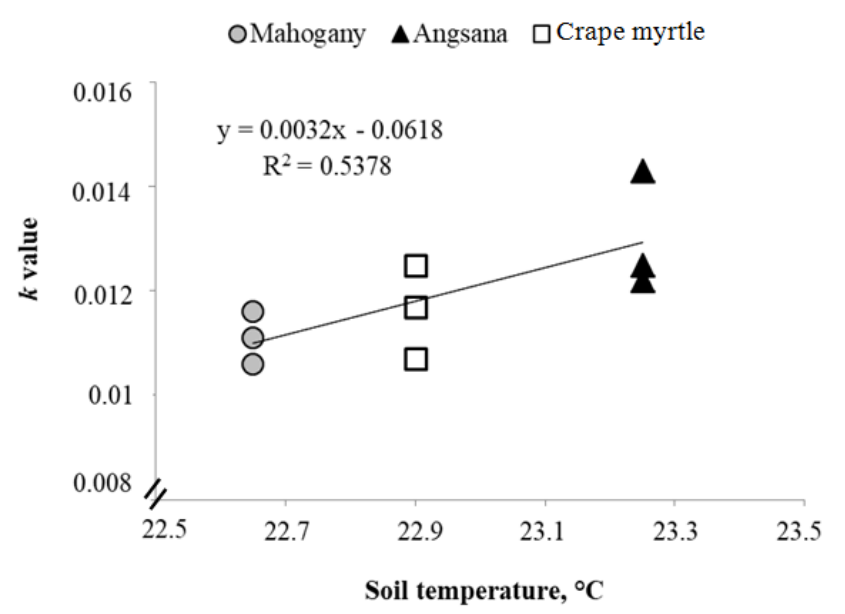

Figure 5 Regression of decomposition rate on soil temperature

Table 5. Regression of decomposition rate ( $\boldsymbol{k}$ value) as y and various litter quality indicators as $\mathrm{x}$

\begin{tabular}{llc}
\hline Litter quality indicator & Equation & $\mathbf{R}^{\mathbf{2}}$ \\
\hline C/N ratio & $\mathrm{y}=0.0235 \mathrm{x}+1.1014$ & 0.6587 \\
Polyphenol concentration $(\mathrm{P})$ & $\mathrm{y}=0.0918 \mathrm{x}+1.0082$ & 0.1244 \\
Lignin concentration $(\mathrm{L})$ & $\mathrm{y}=-0.0286 \mathrm{x}+1.2557$ & 0.0859 \\
L/N ratio & $\mathrm{y}=-0.0223 \mathrm{x}+1.3172$ & 0.2102 \\
$(\mathrm{~L}+\mathrm{P}) / \mathrm{N}$ ratio & $\mathrm{y}=-0.0075 \mathrm{x}+1.273$ & 0.0558 \\
\hline
\end{tabular}




\section{Visitors' perspectives to "cleanliness" of litter-free areas}

Based on interviews involving 100 respondents, it was found that most visitors were well aware of the benefits of litter itself and they did not feel disturbed by the presence of litter on the ground. According to the results of interviews with visitors who generally come for recreation, litter on the ground does indeed reduce the attractive beauty of the botanical gardens because it is less attractive to look at it and reduces the level of comfort of visitors. This is reflected in the selection of areas where litter is frequently removed by park staff that made garden looks clean and neat. On the other hand, the formation of a thick litter layer is more attractive for visitors to enjoy happy days under the shade of trees with thick and flat stretches of brown litter. Attractive tourist area is a potency that drives the presence of tourists to a tourist destination (Suwantoro 2004).

Efforts to increase the attractiveness of PBG can be done by improving cleaning services in several locations that are visited by many visitors. Litter can be used for compost based material and returned to the land to maintain soil health and plant beauty in the Purwodadi Botanical Gardens. For the area where litter is not cleaned, it can be used as a special attraction to capture the beauty of the 'tropical autumn'.

In conclusion, the angsana/narra litter decomposed faster in its 'own home' and had a shorter half-life time $\left(\mathrm{t}_{50}\right)$, with $\boldsymbol{k}$ value $=1.0935$ and $\mathrm{t}_{50} 48$ weeks, while in the neighbors home $\boldsymbol{k}$ value $=1.0723$ to 1.055 with $\mathrm{t}_{50}=55$ and 57weeks. For bungur/crape myrtle litter decomposition rates is slower in its own-home $k=1.0398$ and $\mathrm{t}_{50}=65$ weeks, while in the neighbors-home $\mathrm{k}$ value $=1.0497$ to 1.0517 with $\mathrm{t}_{50}=55$ to 59 weeks. The decomposition rate of mahogany litter is independent of location, $\boldsymbol{k}$ value ranging from 1.0337 to 1.0446 with $t_{50} 60$ to 65 weeks.

Visitors know well the benefits of litter and do not feel disturbed by the presence of litter on the soil surface. The formation of a thick litter layer increases the attractiveness for visitors to enjoy happy days under the shade of trees with thick and flat brown litter cover.

\section{ACKNOWLEDGEMENTS}

We acknowledge the valuable input from Prof. Meine van Noordwijk (ICRAF, Nairobi-Kenya) that improved this paper. The financial support for this publication partly given by WCU (World Class University) program UBSAMA (Analisis Skenario untuk Mengelola Agroforest) TA 2019.

\section{REFERENCES}

Aerts R. 1997. Climate, leaf litter chemistry and leaf litter decomposition in terrestrial ecosystems: a triangular relationship. Oikos 79 (4): 39-49

Anderson JM, Ingram JS. 1993. Tropical soil biology and fertility: a handbook of methods 2nd (Ed.). CAB International, Wallingford, UK
Austin AT, Vivanco L, González-Arzac A, Pérez LI. 2014. There's no place like home? An exploration of the mechanisms behind plant litter-decomposer affinity in terrestrial ecosystems. New Phytol 204 (2): 307-314.

Ayres E, Stelzer H, Berg S, Wall DH. 2009. Soil biota accelerates decomposition in high-elevation forests by specializing in the breakdown of litter produced by the plant species above them. J Ecol 97: 901-912.

Binkley D, Adams MA. 2019. Ecology and management of forest soils. Wiley-Blackwell, New Jersey, US.

Bradford MA, Berg B, Maynard DS, Wieder WR, Wood SA. 2016. Understanding the dominant controls on litter decomposition. J Ecol 104 (1): 229-238.

Clarke SR, Norman JM. 1995. Home ground advantage of individual clubs in English soccer. Statistician 44: 509-521.

Gholz HL, Wedin DA, Smitherman SM, Harmon ME, Parton WJ. 2000. Long-term dynamics of pine and hardwood litter in contrasting environments: toward a global model of decomposition. Glob Change Biol 6: 751-765

Goering HK, Van Soest PJ. 1970. Forages fiber analyses apparatus, reagents, procedures, and some application. USDA Agric, Handbook, Washington DC.

Hairiah K, Sulistyani H, Suprayogo D, Widianto, Purnomosidhi P, Widodo RH, van Noordwijk M. 2006. Litter layer residence time in forest and coffee agroforestry system in Sumberjaya. West Lampung. For Ecol Manag 224 (6): 45-57.

Hairiah K, Widianto, Utami SR, Suprayogo D, Sitompul SM, Sunaryo, Lusiana B, Mulia R, Van Noordwijk M, Cadisch G. 2000. Pengelolaan Tanah Masam Secara Biologi: Refleksi Pengalaman dari Lampung Utara. ICRAF, Bogor. [Indonesian]

Joly FX, Milcu A, Scherer-Lorenzen M, Jean LK, Bussotti F, Dawud S M, Muller S, Pollastrini M, Ruulund-Rasmusses K, Vesterdal L, Hattenschwiler S. 2017. Tree species diversity affects decomposition through modified micro-environmental conditions in European forests. New Phytol 214: 1281-293.

Midgley MG, Brzostek E, Phillps RP. 2015. Special feature-standard paper, Whether in life or in death: Fresh perspectives on how plant affect biogeochemical cycling. Decay rates of leaf litters from arbuscular mycorrhizal tree are more sensitive to soil effects than litters from ectomycorrhizal trees. J Ecol 103: 1454-1463.

Mafongoya PL, Giller KE, Palm CA. 1998. Decomposition and nitrogen release patterns of tree prunings and litter. Agrofor Syst 38: 77-97.

Olson JS. 1963. Energy storage and the balance of producers and decomposers in ecological systems. Ecology 44: 322-331.

Palm CA, Sanchez PA. 1991. Nitrogen release from some tropical legumes as affected by lignin and polyphenol contents. Soil Biol Biochem 23: 83-88.

Peraturan Presiden No. 93 Tahun 2011 Tentang Kebun Raya. [Indonesian]

Schuur EAG, Chadwick OA, and Matson PA. 2001. Carbon cycling and soil carbon storage in mesic to wet Hawaiian montane forests. Ecology 31: 82-96.

Slovin MJ. 1960. Sampling. Simon and Schuster Inc., New York.

Sun OJ, Campbell J, and Law BE. 2004. Dynamics of carbon stocks in soil and detritus across chronosequences of different forest types in the Pacific Northwest. USA. Glob Change Biol 10: 70-81.

Suwantoro G. 2004. Dasar-dasar pariwisata. Penerbit Andi, Yogyakarta. [Indonesian]

Tejada JJ, Punzalan JRB. 2012. On the misuse of Slovin's formula. Philippine Statistician 61 (1): 129-136.

Veen GFC, Freschet GT, Ordonez A, Wardle DA. 2015. Litter quality and environmental controls of home field advantage effects on litter decomposition. Oikos 124 (2): 187-195.

Vivanco LA, Rascovan N, Austin AT. 2018. Plant, fungal, bacterial and nitrogen interactions in the litter layer of native Patagonian forest. Peer J. https: //peerj.com/articles/4754.pdf

Wang J, You Y, Tang Z, Liu S, Sun OJ. 2015. Variations in leaf litter decomposition across contrasting forest stands and controlling factor at local scale. Plant Ecol J 8 (3): 261-272.

Zimmerman M, Davies K, Pena de Zimmerman VTV, Bird MI. 2015. Impact of temperature and moisture on heterotrophic soil respiration along a moist tropical forest gradient in Australia. Soil Res 53: 286297. 